\title{
肝硬変併存食道癌の治療
}

\begin{tabular}{lllll}
\multicolumn{5}{c}{ 防徫医科大学校第 2 外科 } \\
島 & 伸吾 & 米川 $\quad$ 甫 & 吉住 & 豊 \\
杉浦 & 芳章 & 大塚八左右 & 尾形 & 利郎
\end{tabular}

\section{OPERATION OF ESOPHAGEAL CANCER IN THE PATIENTS WITH LIVER CIRRHOSIS}

\section{Shingo SHIMA, Hajime YONEKAWA, Yutaka YOSHIZUMI, Hassau OTSUKA and Toshirou OGATA}

National Defemce Medical College, 2nd Department of Surgery

象引用語：肝硬変併存食道癌, 食道癌, 食道癌術後合併症

はじめに

近年食道癌の手術適応が拻大され併存疾患を有する 症例子切除の対象にされることが多くなってきた。 1978年から1984年までに92例の食道癌を切除し，うち 5 例 $(5.4 \%)$ に肝硬変の併存が認められた。このらち 術前に肝硬変症が診断されていたものは 3 例で， 2 例 は術中に発見された。この 5 症例の術前検查値, 術中, 術後の特異性について検討した（表 1 ）.

\section{1. 症 例}

症例 1.TU, 42歳男性, Ei-Im(食道癌取り扱い規的 ${ }^{1)}$ による）に $11 \mathrm{~cm}$ ラセン型の食道癌があり，40Gy の術 前照射後手術をおこなった。術前検査で TTT 13.8 , ZTT 19.3と高值を示したが indocyanine green test 15分値 (以下 ICG R15と略す) が3.3\%であった．開腹 したところ肝硬変の程度は軽く, 静脈の怒張も軽度な ので．定型的に胃管を作成し，右開胸で下部食道切除 後. 右胸腔内食道胃吻合術を行った. 肉眼的には $\mathrm{A}_{2}$, $\mathrm{N}_{2}, \mathrm{M}_{0}, \mathrm{Pl}_{0}$ で Stage III と判定した。組織学的には $\mathrm{a}_{1}$, $\mathrm{n}_{3}$ で stage IV で肝の生検で precirrhotic stage と診 断された。術後は腹痛，下㾋を時々認め，同時に血中 amylase が高值を示し慢性䐙炎を合併しているすの と考学られた。現在術後 6 年生存中でTTT $24, Z T T$ 28.5 と高値を示しているが, 再発や静脈瘤の徵候は認 められない。

症例 $2 . \mathrm{HO}, 62$ 歳男性, Im 亿6 $\mathrm{cm}$ の鋸歯型食道癌 があり，他院で $40 \mathrm{~Gy} \mathrm{Co}$ 照射後当院へ紹介された，入

$<1986$ 年 5 月 31 日受理 $>$ 別刷請求先：島 伸吾 于359 所沢市並木 3-2 防衛医科大学校第 2 外科
表 1 肝硬変併存食道癌症例

\begin{tabular}{|c|c|c|c|c|c|c|c|c|}
\hline 豦 & 年 & 繁 & itage & $\begin{array}{l}\text { 前 } \\
\text { 敬 } \\
\text { 治 }\end{array}$ & $\begin{array}{l}\text { 肝 } \\
\text { 硓 } \\
\text { 変 }\end{array}$ & 雨式 & 合併证 & 予挠 \\
\hline 1 & $\begin{array}{l}42 \\
\mathrm{M}\end{array}$ & $\underset{11}{E i}$ & 4 & 4000 & $z$ & 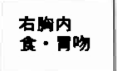 & 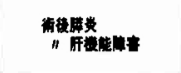 & $\begin{array}{l}\text { 6年 } \\
\text { 生存中 }\end{array}$ \\
\hline 2 & $\begin{array}{l}62 \\
\dot{M}\end{array}$ & $\begin{array}{l}\text { Im } \\
6\end{array}$ & 4 & 4000 & 甲 & 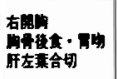 & 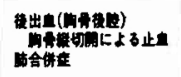 & 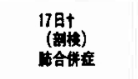 \\
\hline 3 & $\begin{array}{c}54 \\
\dot{M}\end{array}$ & $\begin{array}{l}\mathrm{Im} \\
6.5\end{array}$ & 4 & How & $\mathbf{z}$ & 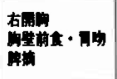 & 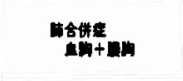 & $\begin{array}{l}\text { 26力月十 } \\
\text { (副模) } \\
\text { 不不全 }\end{array}$ \\
\hline 4 & $\begin{array}{l}56 \\
\dot{M}\end{array}$ & $\begin{array}{l}\text { Im } \\
\text { Ei } \\
12\end{array}$ & 1 & $\Theta$ & $z$ & 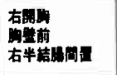 & 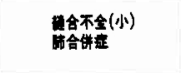 & 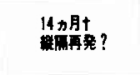 \\
\hline 5 & $\begin{array}{c}71 \\
\dot{\mathbf{M}}\end{array}$ & $\begin{array}{l}\mathrm{Ce} \\
\mathrm{lu} \\
6.5\end{array}$ & 4 & $\Theta$ & z & 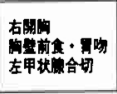 & 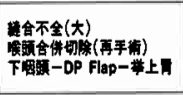 & 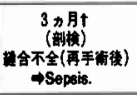 \\
\hline
\end{tabular}

院時 GOT 730, GPT 950 と高値を示したが強力ミノ ファーダンCの治療により 2 週間後にはGOT 74, GPT 81 と低下した. しかし肝 CT (computed tomography（以下 CT と略す） scan（図 1)，拉よび超音波 検查で肝左葉外側区域の内側よりに $1 \times 1.5 \mathrm{~cm}$ の肝転 移を認めた。

1982年12月 13 日右開胸で胸部食道全摘後, 開腹し肝 左葉外側区域を合併切除し，胸骨後食道胃吻合術を施 行した。胸骨後にトンネルを作成中, 胸骨後の上部よ り出血を認めたがガーゼタンポンで減少したので胃管 による压迫止血に期待し，胃管に沿って胸骨後腔にド レーンを挿入して手術を終了した，出血量は $1,400 \mathrm{ml}$

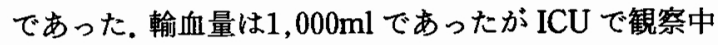
胸骨後腔のドレーンよりの出血が続き，生血の輸血に るかかわらず出血量が減らなかったので再手術を決定 
図 1 症例 2 の腹部 CTscan 像, 肝左葉内側区域に $1.5 \times 1.0 \mathrm{~cm}$ の転移を認める。

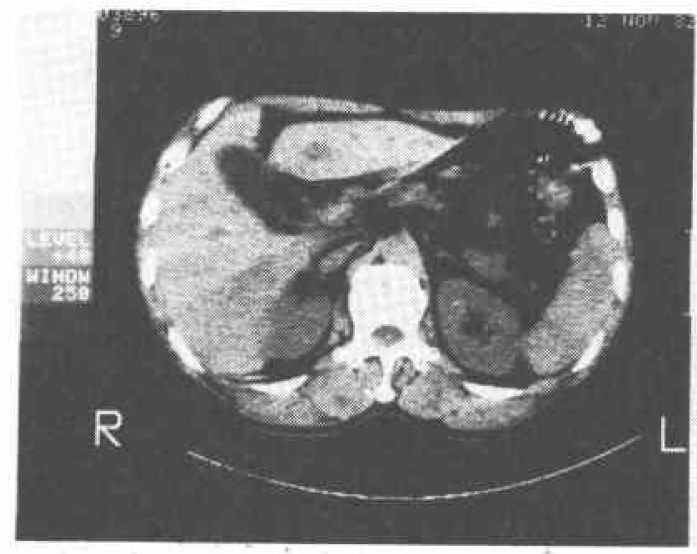

し同日，胸骨縦切開により止血術を行なった，胸骨後 腔に $500 \mathrm{ml}$ 程度の凝血があり，これる除去すると肝硬 変のため太くなっていたと思われる縦隔側の血管を損 傷していたことが確認され止血に成功した。術後 1 週 間後にレスピレーターより離脱できたが，12日目ころ より胸部X線写真に左肺のみに一様にスリガラス様陰 影を認めるようになり, 再度レスピレータ一を装着し 治療につとめたが徐々に一側珄肺不全が進行し, 術後 17日目に死亡した。剖検の結果, 左肺全体に線維化を 伴った肺炎像を認めるほかには著変はなかった。組織 学的には $\mathrm{mp}, \mathrm{n}_{0}, \mathrm{pl}_{0}, \mathrm{~m}_{1}, \mathrm{Ef}_{3}$ で Stage IV となり, 肝 は甲’型肝硬変であった。

症例 $3 . \mathrm{KT}, 54$ 歳男性. Im に6.5 cm のラセン型腫 瘍があり，他院で40Gy Co 照射後本院へ紹介された。 入院時検査では GOT 48, GPT 58 と軽度の異常を認め る注かは著変なく，1983年 1 月19日に右開胸で胸部食 道全摘, 出血量が $520 \mathrm{ml}$ とやや多かった. 開腹時, 腹水 はほとんどなかったが，腫大し硬い肝が胸壁前に挙上 する胃管を王迫するので肝を前側に折りまげるよらに 固定し，ようやく頸部にとどかせることができた，同 時に脾摘もおこなった。 肉眼的に $\mathrm{A}_{3}, \mathrm{~N}_{3}, \mathrm{Pl}_{0}, \mathrm{M}_{0}$ と判 定, 出血量は $1,890 \mathrm{ml}$ であった。組織学的には $\mathrm{a}_{2}, \mathrm{n}_{2}$, $\mathrm{Ef}_{2}$, 肝は posthepatic cirrhosis 乙型と判定された。術 後 3 日目に胸腔ドレーンより $900 \mathrm{ml}$ の出血を認めた が, 生血輸血 $800 \mathrm{ml}$ で止血に成功し14日後には胸腔ド レーンを拔去することができた。しかしその後約 1 カ 月間38〜 $39^{\circ} \mathrm{C}$ の発熱が続き, 胸部 X.P で右胸部に胸水 の貯留が増加してきたので，胸腔穿刺を行ったが癒着 による隔壁ができていたためか十分に排液できなかっ
た.しかし CT scan 検査で胸腔内膿瑝と診断がつきド レナージ後洗浄を繰り返し治癒せしめ，3力月後に退 院させることができた。退院後経過はしばらく良好で あったが 2 年後に肝不全となり死しした。剖検の結果 再発はなく肝不全による死亡と確認された。

症例 4.TI 56歳男性, 1980年 1 月26日吐血し近医で Sengstaken Blakemore tube で止血されたが 2 月 12 日再出血したため当院へ緊急入院し，2月14日に左開 胸で食道離断術を施行した。 4 月 16 日 2 期的に脾摘, 胃上部血行郭清を施行。この時の肝生検で乙型肝硬変 と診断された。 58 年始めごろより䜩下困難があったが 放置しており1983年 9 月に呕吐して近医受診し食道癌 と診断され本院へ紹介された. Im に $12 \mathrm{~cm}$ の腫瘤型食 道癌が認められた。1983年 9 月26日右開胸し胸部食道 を全摘したが，下縦隔は前回の食道離断術のため瘾着 が強く郭清術は不十分であった，奇静脈などる瘄着の 中に含まれていたが大動脈に沿ってなんとか䟝離でき たが，肉眼的にはA3とした．開胸中の出血量は470m であった．開腹したところ上腹部はやはり瘜着が強く 胃を剝離することを諦め, 右半結腸を胸壁前に挙上し 食道と胃の間に有茎移植した。術中進行度は $\mathrm{A}_{3}, \mathrm{~N}_{0}$, $\mathrm{M}_{0}, \mathrm{Pl}_{0}$ と判定したが, 組織学的には $\mathrm{a}_{0}, \mathrm{n}_{0}, \mathrm{ly}+, \mathrm{v}+$, ow一, awーであり，術中出血量は $840 \mathrm{ml}$ であった，術 後は嗄声と頸部に minor leakage を認め, 約20日間 $38 \sim 38.5^{\circ} \mathrm{C}$ 発熱があったが軽快し術後40日で退院し た，その後 1 年は経過良好であったが13カ月後，心囊 タンポナーデとなり死亡した。剖検できなかったが綎 隔すなわち局所再発と考㝋ている.

症例 5.TK, 71歳男性. Celu の6.5cm ラセン型食道 癌症例である。1984年 6 月より嚥下障害があり耳鼻科 を受診し食道癌と診断されたが放置していた８月に 症状が強くなり入院した。難聴が強く人との contact ができにくいので,できるだけ喉頭を温存する方針で, 1984年 9 月 3 日右開胸で胸部食道全摘, 次いで開腹し たが腹水はなく肝は乙型肝硬変で肉眼的には $\mathrm{A}_{3}$ すな わち甲状腺への浸潤， $\mathrm{N}_{2}, \mathrm{Pl}_{0}, \mathrm{M}_{0}$ と判定した。胸壁前 に胃管を挙上し甲状腺の左葉を合併切除しできるだ け高い位置で食道胃吻合を行った。組織学的にも甲状

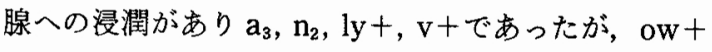
であった. 術後は反回神経麻瘏から肺合併症を併発し たので気管切開しレスピレーターを使用した。術後 10 日目ごろより縫合不全がおこり, さらに気管切開孔の 左壁が壊死化したため口側断端癌遺残のことも考光, 10月15日に喉頭および吻合部を切除し，永久気管瘦を 
作り, 大胸筋皮弁で下咽頭と挙上胃管の間を接続した。 この手術で ow は癌陰性にできたが，2回目の手術後 2 週目頃より皮弁と胃管の吻合部のところに leakage が認められ徐々に抎大していくので bed side で再縫 合をしたところ12月始めに菌血症となり在院死亡と なった。

\section{2. 術前検查值について}

表 2 に示すように末梢血挆よび肝機能検查値を食道 癌患者の中で肝硬変併存 5 例之対照 87 例について比較 検討した，WBC 拉よび血小板数は肝硬変群で有意に 少なかった. $\mathrm{RBC}, \mathrm{Hb}$ は差を認めなかった. 肝機能検 查ではT.B., GOTなどは差を認めなかった。しかし GPT 拉よび $\mathrm{A} / \mathrm{G}$ で有意差があり，注かに肝硬変群で はコレステロールはやや低く, TPはやや高い傾向が 認められた。アルブミン量は有意差は認められなかっ た. ICG $\mathrm{R}_{15}$ は術前に肝硬変症と診断されていた 3 例 にのみ行われたが，それぞれ3.3\%，10.3\%，18.3\%と

1 例に中等度の障害を示しただけであった。

\section{3. 術中術後の経過}

肝硬変併存症例 5 例は前述のよ5に肝硬変非併存例 にくらべて,やや複雑な手術が行われた傾向はあるが, 手術時間を比較してみると肝硬变群 5 例では 380 分士

\section{表 2 術前検查值}

\begin{tabular}{|l|c|c|c|}
\hline & 肝硬变 5 倒 & 対照87例 & \\
\hline 年 令 & $57 \pm 10$ & $64 \pm 10$ & $P<0.2$ \\
\hline WBC & $3900 \pm 1200$ & $6600 \pm 2200$ & $\mathbf{P}<0.02$ \\
\hline RBC & $374 \pm 52$ 万 & $407 \pm 51$ 万 & N.S. \\
\hline Hb & $12.2 \pm 1.3$ & $12.8 \pm 1.5$ & N.S. \\
\hline 血小板 & $17 \pm 5$ 万 & $26 \pm 7$ 万 & P $<0.02$ \\
\hline T.B. & $0.7 \pm 0.1$ & $0.6 \pm 0.2$ & N.S. \\
\hline GPT & $62 \pm 24$ & $25 \pm 20$ & $\mathbf{P}<0.01$ \\
\hline Chol & $152 \pm 49$ & $177 \pm 42$ & $\mathbf{P}<0.2$ \\
\hline TP & $7.2 \pm 0.6$ & $6.8 \pm 0.6$ & $\mathbf{P}<0.2$ \\
\hline A/G & $1.1 \pm 0.1$ & $1.3 \pm 0.3$ & $\mathbf{P}<0.05$ \\
\hline Aibumin & $3.5 \pm 0.2$ & $3.8 \pm 0.5$ & N.S. \\
\hline
\end{tabular}

表 3

\begin{tabular}{|c|c|c|c|}
\hline & 肝硬变 5 例 & 対照87㑬 & \\
\hline 手 術時 間 & $380 \pm 50$ 分 & $340 \pm 60$ 分 & $P<0.1$ \\
\hline 術中出直量 & $920 \pm 530 \mathrm{ml}$ & $560 \pm 410 \mathrm{ml}$ & $P<0.1$ \\
\hline $\begin{array}{l}\text { 衙中〜術後 } 5 \text { 日 } \\
\text { 輪 血 }\end{array}$ & $1820 \pm 1050 \mathrm{ml}$ & $770 \pm 750 \mathrm{ml}$ & $P<0.01$ \\
\hline 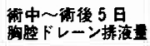 & $1970 \pm 1250 \mathrm{ml}$ & $1060 \pm 620 \mathrm{ml}$ & $P<0.01$ \\
\hline
\end{tabular}

50 分. 対照群で 340 分 \pm 60 分 $(\mathrm{p}<0.1)$ とやや長い傾向 がみられた。 また術中出血量を比較したところ肝硬変 群で $920 \pm 530 \mathrm{ml}$, 対照群 $560 \pm 410 \mathrm{ml}(\mathrm{p}<0.1)$ であっ た。しかし術後の出血量や排液量に差があるのではな いかと考え, 術中から第 5 病日までの胸腔ドレーンよ りの排液量を比較したところ肝硬変群では総計 $1,970 \pm 1,250 \mathrm{ml}$, 対照群では $1,060 \pm 620 \mathrm{ml}(\mathrm{p}<0.01)$ とあきらかな差が認められ，同時にこの期間の輸血量 をみると肝硬変群で $1,820 \pm 1,050 \mathrm{ml}$, 対照群で770土 $750 \mathrm{ml}(\mathrm{p}<0.01)$ と有意差を示した.

\section{考察}

肝硬変併存食道癌の治療成績についての報告は少な く, 山名ら ${ }^{21}$ は食道癌症例の $6.2 \%$ にたる 12 例につい て報告し内 2 例の生存例を認めるのみである. 一方岡 ら $3 /$ は肝硬変併存食道癌の直死率 $62.5 \%$, 術後の合併 症発生率も $87.5 \%$ と術後管理のむつかしさを強調して いる.今回 5 例の肝硬変併存食道癌を経験したが頻度 としては切除食道癌症例の $5 \%$ にあたり全例なんらか の術後合併症は認めたが，直死例は 1 例(20\%), 3 力 月の在院死亡が 1 例あったが 3 例は無事退院できた. 肝硬变併存食道癌の手術例の報告は少ないが肝硬変む 食道癌子领酒との間にある程度因果関係が示唆されて いる現在, も5少し症例があってもよいと思うが, 切 除適応から除外されている例る多いのではないかと予 想される。

ちなみに猪狩ら゙)は食道癌52例中 3 例 $6 \%$ K合併を 認めたが，全例手術適応はなかったとしてる. Kayser $ら^{5}$ ) は115例の食道癌の剖検例の $8 \%$ に肝硬変の併存 があり, heavy drinkerに食道癌の発生が多いことを 示唆している。これらのことより今後すすます併存症 例は増える可能性は高いと思われる．術前の問題点と して山名ら 2)は肝予備力からみた手術適応基準を示し ているが ICG 検查, 血清 albumin 量が良い指標とな るようである。岡ら゙は術前肝機能障害患者につき直 死例と生存例を比較検討した結果, bilirubin, ALP 值 は直死例でやや高く, Ch. E., albumin 值で有意に低值 を示したとしている。自験の 5 例では, 術前に肝硬变 が診断されたすのは 3 例にすぎず，あとの 2 例は術中 に発見されたもので，䀒予備能についての検討はでき なかった。そこで術前の一般検査で肝硬変併存を示す ヒントが得られないかと検討したところ，WBC，血小 板, GPT, A/G で明らかな差を認め, 住かに cholesterol はやや低く,TPはやや高い傾向を示した。これらの 術前検查值を参考にして今後はできるだけ術前に予知 
し，肝予備能を仔細に検查すべきと考えている，術中 の問題点としてはすず術式がやや複雑になり，特に食 道静脈瘤の手術がすでにおこなわれた症例では胸部, 腹部ともに瘑着が強く十分な郭清術は困難なうえ，再 建臟器の選択に苦虑しなければならない，特に空腸を 有茎で挙上すると空腸内に静脈瘤ができる可能性を念 頭に入れておくべきである。 また脾摘を拈こなうべき か，腫大した肝のうえを胃管を通す時の工夫などいろ いろ問題があるが, 術後合併症が多いことを考充，で きるだけ安全な術式を選択すべきである。すず止血を 厳重に和こならこと, 代用食道を挙上する経路として 盲目的な胸骨後より良い視野が得られる胸壁前経路が 良いと思われる。自験例では術中腹水は汪とんどみら れなかったが，それでも術後に 3 例腹水貯留を経験し たので腹腔にもドレーンを入れて打くほうが良いと思 われる. 術後の問題点は遠隔成績は別にして, 現時点 では少なくとも在院死亡をさける努力をすべきだと思 5. 術中術後 Swan-Ganzのカテーテルを使って血行 動態をモニターしながら輸液を行ってもな打肺合併症 が多く,胸水や腹水のコントロールに難渋させられる。 これに関し, 川原田ら ${ }^{6}$ は肝障害を併存した消化器手 術の術中, 術後の管理として, 特に肝硬変症例では肺 内シャント率が著しく增加して招り,さらに colloid oncotic pressure (COP) が17mmHg 以下の症例では 高率に肺水腫が発生するといっている。われわれは肝 硬変併存例では術後早期より大量の凍結, または液状 血浆, さらに輸血としては新鮮血を使用し血小板や血 清脂質などの補給を行っているため, 低蛋白血浆, 低 コレステロール，出血傾向などもみられなかった。そ れにもかかわらず縫合不全をはじめとして炎症症状が 続き在院期間が長くなる傾向が認められた。ささらに術 後の肝機能る一時的に悪化することが多く, 長びく炎 症に対し種々の抗生剂を使用することが重なり，肝腎
障害を抗こしやすい，以上のように悪条件が重なるの で術啳合併症はある程度招こるものと覚悟し，それが 致命傷にならないようにすることが必要と思われる。 そのためには慎重かつ厳重に管理する必要があり, 特 に術後の栄養, 血浆を中心とした輸液, 血獍漫透圧の 測定, 感染予防に注意し, さらに肝, 腎機能の推移に 注目すべきであると思ら。

\section{結 語}

1. 肝硬変併存食道癌 5 例を報告した.

2. 術前一般検查で WBC, 血小板, GPT, A/G で対 照群と肝硬変群の間に有意差があった。

3. 手術時間。術中出血量にわずかな差があったほ か, 術中から 5 日目までの胸腔ドレーンからの総排液 量,および総輸血量には明らかな差が認められた。

4. 全例なんらかの合併症をおこしたが, 直死例は 1 例, 在院死亡は 1 例， 6 年生存中が 1 例あった。

$$
\text { 文献 }
$$

1）食道疾患研究会編：食道癌取扱い規約. 東京, 金原 出版, 1976, p 2-3

2）山名秀明, 掛川輝夫, 岩元元一澡か：肝硬変併存食 道癌の外科的治療. 日消外会誌 $17: 1918-1921$, 1984

3）岡 正朗, 石上浩一,村上卓夫ほか：教室に招ける 他葴器の機能障害をるった食道癌の外科的治療. 日消外会誌 $17: 1922-1925 ， 1984$

4）猪狩次郎, 片場嘉明, 生田目公夫ほか：食道静脈瘤 に合併した食道癌の臨床的検討.日消外会誌 $16: 2151,1983$

5) Kayser K, Burkhardt HU: Population based pathology statistics of oesophageal carcinoma. J Cancer Res Clin Oncol 105:292-298，1983

6）川原田嘉文, 水本龍二：肝障害合併例に対する術 前, 術後の管理. 日臨外医会誌 $44: 334-338$, 1983 